\title{
NÁKUPNÍ STRATEGIE - SINGLE A MULTIPLE SOURCING
}

\section{Jana Kašparová}

\section{Klíčová slova:}

Strategie, nákupní strategie, single sourcing, multiple sourcing

\section{Key words:}

Strategy, purchasing strategy, single sourcing, multiple sourcing

\begin{abstract}
Abstrakt
Článek se zabývá problematikou strategie a strategického řízení v oblasti nákupu, jako organizační jednotky podniku, případně z hlediska funkcionalit nákupní činnosti. Detailně rozebírá rizika, výhody i nevýhody strategie single a multiple sourcingu jak z pohledu vnitřních záležitostí podniku, tak i z pohledu vnějšího obousměrného vztahu mezi podnikem a jeho tržním okolím.
\end{abstract}

\begin{abstract}
This article pursues issues of strategy and strategic management in area of purchasing (procurement) as the department in organizational structure of the company and from the position of its functions. Further the article ruminates over the risks, advantages and disadvantages of single and multiple sourcing strategies in connection to internal affairs of the company and also to external reversible relation between the company and its market surroundings.
\end{abstract}

\section{Úvod}

Cílem tohoto článku je posoudit a analyzovat rozdíly mezi strategiemi single a multiple sourcingu $\mathrm{v}$ podmínkách oligopolního trhu s částečně diferencovaným produktem $\mathrm{v}$ případě nákupu položek se zcela strategickým významem pro uvažovaný podnik.

Při přípravě článku byly využity zejména metoda analýzy, metody indukce a dedukce a metoda komparace. Východiskem článku bylo studium odborných pramenů vztahujících se k problematice volby zdrojů nákupu. Posouzení pozitiv a negativ strategií single a multiple sourcingu ve druhé části bylo vypracováno jednak na základě určité formy kvantitativního výzkumu omezeného rozsahu uskutečněného na malé skupině podniků, jejichž strategické vstupy odpovídají charakteristikám definovaným v rámci cíle, avšak neopominutelný význam při přípravě tohoto článku sehrála rovněž metoda brainstormingu uskutečněného za účelem posouzení a tvorby nové nákupní strategie, tedy zejména za účelem evaluace výhod a nevýhod odlišných př́stupů k volbě zdrojů nákupu konkrétního vybraného podniku. Tyto výsledky byly následně generalizovány a staly se základem pro vypracování druhé kapitoly tohoto článku.

\section{Strategie nákupu}

„Pod strategií se rozumí návrh a provedení celkového konceptu, podle kterého podnik v soutěži s jinými konkurenty hledá dosažení určité cílové pozice““(Mallya, 2007). 
Odborná literatura uvádí celou řadu definic strategie, strategického myšlení i popisu jeho principů. Za všechny lze uvést zejména požadavek na proaktivnost, inovativnost a kontinuitu, kreativita a komplexnost.

Pro strategii, at' už se jedná o strategii celého podniku, nebo jeho nejmenší organizační jednotky, platí zásadní pravidlo - nic nesmí být viděno jako nehybné a neměnné. Naopak, strategie a strategické myšlení musí být stejně tak dynamické, jako je podnik sám (Mallya, 2007). Toto pravidlo nabývá na významu zejména v prostředí rostoucí globalizace a koncentrace světových trhů.

Strategie nákupu jsou v některých odborných zdrojích řazeny mezi funkční (operativní) strategie na nejnižší úrovni hierarchie firemních strategií, které vycházejí v první řadě z podnikatelské strategie ( $\mathrm{tj}$. strategie na společenské úrovni), následně ze strategie podnikové, tedy korporační nebo firemní strategie na vrcholové úrovni organizace (Keřkovský, Vykypěl, 2006).

Toto chápání nákupní strategie čistě jako strategie funkční je však v posledních letech do jisté míry přehodnocováno - chápání báze nákupní strategie se přesouvá z oblasti „operativního opatřování - zásobování“ do oblasti strategického řízení (Synek, Kislingerová, 2010).

Obdobně jako je tomu u ostatních strategií, i strategie nákupu je výsledkem podrobné situační analýzy, vycházející ze strategie a strategické analýzy celého podniku, jeho okolí a podmínek, za nichž působí.

Strategické řízení $v$ oblasti nákupu je možné realizovat $\mathrm{v}$ analogických krocích jako strategické řízení na celopodnikové úrovni. Jedná se kontinuální proces, na jehož počátku stojí vymezení poslání firmy (nákupního útvaru) a cílů a strategická analýza, následuje etapa generování možných alternativ, optimalizace a výběr strategie, implementace strategie a zhodnocení realizace strategie. V praxi se setkáváme s prolínáním uváděných etap, jejich vzájemnými interakcemi a nutností komplexního př́stupu ke tvorbě strategie a strategickému řízení bez jednoznačného členění do jednotlivých fází.(Keřkovský, Vykypěl, 2006)

Základním předpokladem pro tvorbu i implementaci nákupní strategie je její bezpodmínečný soulad s celopodnikovou strategií, resp. aplikace těch oblastí celopodnikových cílů týkajících se nákupu do nákupního chování dané organizace. V opačném př́padě tato strategie nejen že není prakticky implementovatelná v praxi, ale stává se pouze bezzubou proklamací tvůrce strategie o určitém žádoucím budoucím stavu. (Keřkovský, Vykypěl, 2006)

Nákupní strategie, stejně tak, jako ostatní typy strategií v sobě zahrnují aspekty racionální a iracionální, tedy aspekty plánovatelné (vypočitatelné) a nevypočitatelné, jež plánovat s úspěchem nelze. Záměrem stratégů je pochopitelně eliminace, resp. maximální snížení podílu iracionálních složek ve strategii ve prospěch složek racionálních. Excelentní strategie jsou ty, jež dovedou predikovat vývoj okolí v několika následných krocích a přizpůsobit jim strategii od počátku. (Mallya, 2007)

\section{Nákupní cíle, typy nákupních strategií}

Vedle obecných, dalo by se říci elementárních cílů nákupu, mezi něž je možno řadit například snížení opatřovacích nákladů, snížení rizika nákupu (rizika nekvality, nedodání), zvýšení kvality a účinnosti nákupní činnosti atd., je zejména v př́ípadě nákupu strategických vstupů pro podnik možno identifikovat i cíle mnohem strategičtějšího rázu s mnohem výraznějším 
dopadem do celopodnikové strategie a celkové pozice podniku na trhu ${ }^{1}$. Z tohoto faktu vyplývá, že snaha o zobecnění cílů nákupu musí být pojata velmi komplexně a že při snaze o jakoukoli generalizaci je nezbytné velmi citlivě vnímat situaci konkrétního podniku, jeho pozici na trhu i zjevné a skryté trendy celého odvětví.

Každý podnik musí vždy zvažovat dvě poněkud odlišná zaměření nákupních strategií. Jedno orientované na vnitřní záležitosti organizace a s nimi spojené úkoly a zodpovědnosti nákupu a druhé pro externí tržní prostředí (Harding, 2001).

Obecně je podle Vávrové, Tomka (2007) možné identifikovat dva základní, avšak zcela odlišné přístupy $\mathrm{k}$ nákupu, které př́ímo determinují způsob, jaká strategie bude zvolena i jakým způsobem bude aplikována. Jedná se o (Vávrová, Tomek, 2007):

- Aktivní chování, které směřuje k dosažení změny a využití rámcových podmínek pro nákupní rozhodování

- Pasivní chování, které představuje pouhá snaha o využití stávajících daných podmínek při rozhodování

Jako třetí by bylo možné zmínit optimální kombinaci obou přístupů v závislosti na konkrétní nakupované komoditě, dodavatelsko-odběratelském vztahu, miŕre rizika, nebo tržní situaci (např. recese versus konjunktura na trhu)

Nedílnou součástí nákupní strategie je i zásadní volba zdrojů - hovoří se tak o sourcingových strategiích ${ }^{2}$, které se stávají stále aktuálnějšími se ve světle vzrůstající globalizace na trhu. V kontextu opatřování základních vstupů pro podnik lze považovat za zásadní dle geografického rozložení (Vávrová, Tomek, 2007):

- Global sourcing - tedy systematické rozšiřování nákupní politiky na mezinárodní zdroje,

- Local sourcing - zaměření na lokální, geograficky blízké zdroje.

Dle počtu dodavatelů lze definovat čtyři základní sourcingové struktury, a to (Cousins, Lamming, Lawson, Squire, 2008):

- Single sourcing - redukce počtu dodavatelů, unifikace zdroje.

- Multiple sourcing - zapojení nejméně dvou a více dodavatelských zdrojů, tedy v podstatě diverzifikace dodavatelského portfolia.

- Delegated sourcing - koncept přenesení odpovědnosti za subdodávku tvořenou několika individuálními částmi z odběratele na klíčového dodavatele.

- Parallel sourcing - výběr zpravidla dvou až tř́i dodavatelů pro skupinu př́ibuzných nákupních položek.

Pro účely tohoto článku jsou zvažovány zejména protipólně orientované strategie single a multiple sourcingu. Obě tyto nákupní strategie s sebou nesou výrazná pozitiva i negativa a to zejména $\mathrm{v}$ oblastech nákladových (zejména cena zboží a přepravné při volbě dodavatele dle geografické vzdálenosti) a v oblasti řízení nákupních rizik. Strategie obecně, a není tomu jinak ani $\mathrm{v}$ př́ípadě strategie nákupu, nemůže být ničím dogmatickým, ani strnulým. V praxi

\footnotetext{
${ }^{1}$ Ačkoli tímto faktem není nijak zpochybněna důležitost kontinuální optimalizace zejména u nákladů na opatřrování nakupovaných položek, přesto i tyto oblasti mohou být odsunuty do pozadí např́íklad rozhodnutím o nutnosti snížení rizika, které by svým potenciálním dopadem mohlo znamenat ohrožení pro fungování podniku - a to i za cenu, či za cenu určitých (akceptovatelných) ústupků např́íklad v cenové a nákladové oblasti.

${ }^{2}$ pro účely tohoto článku je pro názvy jednotlivých sourcingových strategií využíváno anglické terminologie. Důvodem je jednak předpoklad o obecném povědomí o významu těchto anglických termínů u české odborné veřejnosti, jednak fakt, že i řada předních českých autorů věnujících se problematice nákupních strategií nevyužívá českých ekvivalentů k těmto termínům - v řadě případů může vynucený přechod k českému překladu těchto termínů působit poněkud násilně.
} 
se naopak zejména u funkčních strategií setkáváme s tak rychlými změnami, až začíná být použití pojmu „strategie“ nesoucího v sobě atribut dlouhodobosti poněkud nevyhovujícím až zavádějícím ${ }^{3}$.

Dilema, zda unifikovat, nebo naopak výrazně diverzifikovat zdroje nákupu je na současném trhu stále velmi živé a diskutované. Obecně je každou z těchto nákupních strategií nutno vnímat v kontextu zásadních priorit každého konkrétního případu nákupu, pro nějž je strategie konstruována. (Vávrová, Tomek, 2007)

\section{Single a multiple sourcing - posouzení pozitiv a negativ}

Posouzení rizik, výhod a nevýhod dvou odlišných přístupů k nákupní strategii, tedy single a multiple sourcingu, je zpracováno dle metod uvedených v úvodní kapitole a vychází pro účely tohoto článku z následujících podmínek a předpokladů:

- je posuzován zásadní vstupní materiál, který má pro podnik strategický význam, a to $\mathrm{z}$ pozice nakupujícího

- jedná se o B-2-B trh, tržní situace s oligopolními charakteristikami (zejména omezený počet potenciálních dodavatelů, technologické, finanční, investiční či jiné bariéry na trhu), vysoká míra integrace subjektů na trhu, vysoká míra koncentrace na trhu

- jedná se o opatřování komodit, u nichž je nutná určitá míra jejich adaptace potřebám odběratele (tj. nejedná se o unifikovaný a na trhu běžně dostupný sortiment - důvody mohou být technologické, výrobní, systémové, legislativní či jiné)

- situace byt' krátkodobé relativní „,nasycenosti nabídkové strany trhu“ - tj. zaplnění kapacit dodavatelů na trhu spojené s nízkou iniciativou prodávajících vyvolávající nutnost aktivního přístupu a otevírání dodavatelsko-odběratelských vztahů ze strany nakupujících.

Za výše uvažovaných předpokladů lze očekávané výhody multiple sourcingu, tedy diverzifikace portfolia dodavatelů definovat následovně.

Vlivy na tržní riziko:

- snížení rizika spojeného s potenciálním nedosažením dohody na požadovaném objemu a ceně u stávajících dodavatelů a případným s tím spojeným výpadkem dodávek,

- snížení rizika spojeného se změnou strategie stávajícího dodavatele,

- snížení rizika spojeného s případným zájmem dodavatele o násilné převzetí svého zákazníka,

- diverzifikace rizika nedodání materiálu způsobeného například vyšší mocí.

Očekávané př́ímé výhody:

- omezení závislosti nakupujícího na dodavateli,

- zvýšení variability nákupů, nové alternativy nákupu,

- snížení vlivu stávajících dodavatelů, snížení jejich vyjednávací síly a pozice, možnosti cenového tlaku na stávající dodavatele,

- potenciální zlepší cenových a nákladových podmínek,

\footnotetext{
${ }^{3} \mathrm{Na}$ základě zkušeností z aplikace nákupních strategií u několika podniků, jež se staly bází pro zpracování tohoto článku, prakticky v pravidelných sinusoidách dochází v určitém období k upřednostňování co nejvyššího počtu dodavatelů a následně při praktickém odkrytí jejích negativ tato strategie ustupuje preferenci single sourcingu, nebo alespoň omezeného okruhu spolehlivých, dlouhodobých a adaptovaných dodavatelů. Bohužel i toto zaměření nákupu v sobě obsahuje mnohá rizika a negativa, a i ta jsou většinou odkryta až praktickou aplikací a stávají se motivem k opětovné změně strategie.
} 
- potenciální konkurenční výhoda v novém dodavateli (v případě nutnosti vysoké míry jeho adaptace požadavkům nového trhu) - možnost dohody na exkluzivitě dodávek (eliminace dodávek konkurenci),

- zvýšení interní flexibility a adaptability systému firmy jako možná konkurenční výhoda pro případné období krizí,

- z dlouhodobého pohledu šance na snížení úrovně zásob možností vykrytí př́ípadného výpadku dodávkou od alternativního dodavatele.

Očekávané negativní dopady spojené s vyšší diverzifikací:

- zpravidla větší geografická vzdálenost nových dodavatelů oproti stávajícím,

- nákladová hlediska - interní i externí:

- přímé náklady na adaptaci nových dodavatelů (např. testování, zkušební dodávky),

- zpravidla vyšší přepravní a cestovní náklady (noví dodavatelé jsou zpravidla geograficky vzdálenější), s tím spojené riziko zvýšení celkových pořizovacích nákladů,

- ztráta úspor z rozsahu (v porovnání s dodávkami od velmi omezeného počtu dodavatelů, případně od dodavatele jediného),

- rizika a negativa spojená s potenciálním prodloužením dodací lhůty, včetně nákladů na eliminaci jejích možných důsledků:

- riziko časového nesouladu dodávky a potřeby materiálu pro výrobu (riziko jak skluzu, tak i příliš brzkého dodání),

- nutnost (alespoň krátkodobě) zvýšení úrovně zásob na skladě (vyšší pojistná zásoba) z důvodu dodávek od neprověřených neadaptovaných dodavatelů, delší doba obratu zásob, vyšší vázanost finančních prostředků,

- organizační záležitosti - zpravidla zajištění dodatečných skladovacích ploch, zvýšená nutnost manipulace s materiálem, požadavky na personální obsazení apod.,

- systémové záležitosti - zpravidla ztráta unifikace v systému, nutnost vyšší evidence, požadavky na informační systém,

- obchodní a strategická rizika:

- rizika plynoucí z vysokého stupně vertikální integrace na trhu (např. rizika spojená s majetkovým propojením potenciálně nových dodavatelů s přímými konkurenty dané společnosti),

- riziko „zneužití“ nově adaptovaného dodavatele ze strany konkurence (v prrípadě značně sofistikovaných dodávek s nutností vysoké míry adaptace dodavatele a vysokých nákladů spojených s touto adaptací),

- riziko selhání dodávek v důsledku selhání nového (nezkušeného, nedostatečně adaptovaného) dodavatele (riziko „druhotné dodávkové neschopnosti“),

- riziko změny strategie stávajících (majoritních) dodavatelů v důsledku změny naší nákupní strategie, riziko změny cenové politiky, v případě dosavadní stabilní dlouhodobé spolupráce s hlavními dodavateli - riziko její ztráty,

- zpravidla dlouhá časová a nákladová náročnost adaptace nových dodavatelů, riziko, že se adaptace nezdaří vůbec (zejména $\mathrm{v}$ případě náročnějších sortimenti̊) - absolutní ztráta vložených nákladů na adaptaci, pokud skončí proces adaptace neúspěchem,

- v případě vysoké vyjednávací síly nových dodavatelů obtížné nalezení konsenzu jak v technických, tak i v obchodních a právních bodech, časová náročnost vyjednávání, zpravidla u nastartování spolupráce nutnost rozsáhlých ústupků a kompromisů (včetně jejich potenciálních negativních důsledků), 
- při nákupu mimo EU licenční a celní problémy,

- z dlouhodobého pohledu se pravděpodobně nejedná o nákladově neoptimálnější strategii (avšak toto není pravidlem).

V př́ípadě volby strategie směřující $\mathrm{k}$ single sourcingu je velká část výhod a nevýhod nastavena (oproti výše uváděným negativům a pozitivům multiple sourcingu) zrcadlově. Aby nedocházelo k jejich zbytečnému opakování v textu (např. snížení vlivu majoritního dodavatele u multiple sourcingu versus zvýšení vlivu majoritního dodavatele u single sourcingu), je výčet u následující strategie proveden velmi stručně a zaměřuje se pouze na základní odlišnosti. To však neznamená, že by strategie single sourcingu v sobě nesla méně rizik nebo výhod než strategie multiple sourcingu. Jak již bylo řečeno v préedešlých odstavcích a kapitolách, podobné zobecňování nebo vyvozování nahodilých závěrů je velmi krátkozraké a ukvapené - vždy je nutné posuzovat danou konkrétní strategii v kontextu konkrétní firmy, konkrétní tržní situace a konkrétních podmínek.

Očekávané výhody strategie single sourcingu pro nakupující subjekt:

- úspory z rozsahu,

- sjednocení, zjednodušení a harmonizace systému nákupu, snížení administrativy nákupu,

- zpravidla (alespoň potenciální možnost) snížení přepravních nákladů,

- v případě spolehlivého dodavatele možnost snižení zásob (úrovně pojistné zásoby), menší finanční náročnost na opatřování,

- možnost vzájemného nastavení systému předávání informací mezi dodavatelem a odběratelem, automatizace předávaných dat, zjednodušení plánování,

- zjednodušení organizačních záležitostí uvnitř podniku (plánování výroby apod.),

- snížení interních nákladů (po ukončení procesu adaptace).

Očekávanými nevýhodami single sourcingu $\mathrm{v}$ nákupu jsou:

- vysoká míra závislosti kupujíćího na prodávajícím - případně plná závislost (nutno důsledně zvážit charakteristiky nakupované komodity, aktuální tržní pozici obou subjektů, jejich vyjednávací sílu, možnost alternativních nákupů, resp. prodejů, výhled vývoje na trhu (konjunktura, recese), dobu nutnou pro př́padnou reakci na změnu podmínek a zajištění alternativního nákupu a detekovat možná rizika),

- vysoká pravděpodobnost rizika (i násilné) dopředné či zpětné integrace,

- předpokladem pro fungování této strategie je existence určitého „regulátoru“, který udrží oboustranný zájem na zachování vzájemně vyvážené spolupráce bez jednostranných zájmů po porušení rovnováhy - funguje za předpokladu, že náklady obětované př́ležitosti pro obě společnosti (jak na straně nákupu, tak i na straně prodeje) zaručí, že daná spolupráce je pro oba subjekty nejoptimálnější volbou.

Velmi silnými interními riziky spojenými s implementací nové strategie nejen v oblasti single a multiple sourcingu jsou zejména:

- nedostatečná míra informovanosti uvnitř firmy,

- nedostatečná motivovanost pracovníků $\mathrm{k}$ realizaci nové strategie zejména v konečné fázi (resp. použití pouze donucovacích a represivních nástrojů), ztráta motivovanosti pracovníků v důsledku špatného strategického řízení,

- př́lišná roztř́̌šstěnost cílů a úkolů, 
- organizační náročnost napříč všemi jednotkami a útvary v podniku,

- nedostatečné personální obsazení neodpovídající požadavkům na implementaci nové strategie, nízká kvalifikační úroveň, nízká flexibilita pracovníků i celých útvarů v podniku,

- nedostatečné finanční zajištění pro implementaci nové strategie,

- nesoulad nákupní strategie se strategií celofiremní,

- podcenění důsledků a vlivu nákupní strategie na celofiremní strategii (např. riziko změny strategie stávajících dodavatelů, zejména v kontextu vysoké míry integrace a propojení subjektů na trhu),

- riziko protichůdného „Zacílení“ jednotlivých funkčních strategií v rámci podniku,

- riziko příliš rychlých změn funkčních strategií a cílů (v tomto případě strategie nákupu) bez dostatečného časového prostoru pro implementační fázi a dosažení výsledků,

- riziko „utajování“ skutečných cílů strategie před pracovníky na nižších stupních řízení (spojeno se snahou o udržení určitého obchodního tajemství, způsobuje však nemožnost kvalitní realizace strategie).

\section{Závěr}

Strategie včetně všech kroků její tvorby a zejména implementace je velice komplexní činností. Poměrně úzkým zaměřením tohoto článku na pouhé dvě vybrané potenciální nákupní strategie bylo usilováno o zmapování důsledků pouze jediné z mnoha strategií podniku, tedy strategie nákupu. Současně je však nutno vnímat existenci a vlivy mnoha dalších strategií v rámci podniku a zejména zaměření nadřazených strategií vyššího významu s celopodnikovým působením, které udávají strategiím nižších pater směr.

Jak je z uvedeného výčtu očekávaných efektů strategie single a multiple sourcingu patrné, ani jednu z těchto sourcingových strategií není možné obecně zavrhnout, nebo naopak vyzdvihnout. Paradoxně však právě tento fakt umožňuje při implementaci vhodné strategie z hlediska daného sortimentu, tržních podmínek a mnoha dalších faktorů dosáhnout konkurenční výhody pro podnik. Základem je však optimální uvedené vybrané strategie „V život“. Obecně je možné uvést, že pokud podnik (a jeho jednotlivé funkční jednotky) zavede optimální metodiku, motivační rámec a management pro flexibilní implementaci a změny strategie a dosažení strategických cílů (bez ohledu na to, zda strategie sama je či není zcela optimální), pak se právě tato schopnost stává silnou konkurenční výhodou, která podniku umožní v turbulentním tržním prostředí adaptovat se na měnící požadavky a podmínky.

\section{Literatura:}

[1] COUSINS, P., LAMMING, R., LAWSON, B., SQUIRE, B. Strategic Supply Management: Principles, Theories and Practice. 1. vyd. Pearson Education Limited, 2008, 309 s. ISBN 978-0-273-65100-0.

[2] HARDING, M., HARDING, M. L. Purchasing. 2. vyd. New York: Barron's business library, 2001, 267 s. ISBN 0-7641-1405-0.

[3] KEŘKOVSKÝ, M., VYKYPĚL, O. Strategické řízení: teorie pro praxi. Praha: C.H. Beck, 2.vyd. 2006, 206 s. ISBN 80-7179-453-8.

[4] MALLYA, T. Základy strategického řizení a rozhodování. Praha: Grada Publishing, a. s., 1. vyd. 2007, 252 s. ISBN 978-80-247-1911-5. 
[5] SYNEK, M., KISLINGEROVÁ, E. Podniková ekonomika. 5., přeprac. a dopl. vyd. Praha: C. H. Beck, 2010, 498 s. ISBN 978-80-7400-336-3.

[6] VÁVROVÁ, V., TOMEK, G. Řízení výroby a nákupu. Praha: Grada Publishing, a. s. 2007, 384 s. ISBN 978-80-247-1479-0

\section{JEL M19}

\section{Ing. Jana Kašparová, MEng.}

student doktorského studia Ekonomika a management

Slezská univerzita v Opavě

Obchodně podnikatelská fakulta v Karviné

Univerzitní nám. 1934/3, Karviná

jkasparova@bonatrans.cz 